\title{
ANTWERP UNIVERSITY RADIOCARBON DATES IV
}

\author{
R VANHOORNE and A D DUBOIS
}

Department of General Botany, University of Antwerp (RUCA)

Groenenborgerlaan 171, B - 2020 Antwerp, Belgium

Samples processed since the last list was published (R, 1978, v 20, no. $3, \mathrm{p}$ 192-199) are reported here. The dates were obtained by liquid scintillation counting of benzene, using laboratory procedures outlined in previous articles (R, 1976, v 18, no. 2, p 151-160; R, 1977, v 19, no. 3, p 383388).

\section{GEOLOGIC SAMPLES}

$$
\text { Belgium }
$$

\section{Booitshoeke series}

Peat and clay layers in W Belgian coastal plain (51 $05^{\prime} 34^{\prime \prime} \mathrm{N}, 2^{\circ} 44^{\prime} 03^{\prime \prime}$ E). Coll and subm Nov 1978 by R Vanhoorne and A D Dubois.

\section{ANTW-316. Booitshoeke 1}

$$
\mathbf{3 2 1 0} \pm \mathbf{5 0}
$$

Base of upper peat layer containing numerous reed rhizomes (Phragmites australis), $5 \mathrm{~cm}$ thick, 125 to $130 \mathrm{~cm}$ depth. Peat is overlain by clay. Comment: date is ca 530 yr younger than IRPA-286 (Baeteman et al, 1979; Baeteman, 1981; Dauchot-Dehon, Van Strydonck \& Heylen, 1981a) in same strat position, but containing no reed rhizomes.

\section{ANTW-315. Booitshoeke 2}

$$
2950 \pm 60
$$

Extracted humic acids from ANTW-316. Humic acids were obtained by boiling peat sample with $\mathrm{NaOH}$, followed by their precipitation by $\mathrm{HCl}$ $2 \mathrm{~N}$ treatment. Comment: small difference between ANTW-315 and -316 reflects only minor percolation of humic acids through overlying clay.

\section{ANTW-317. Booitshoeke 3}

$3680 \pm 50$

Wood (Alnus) in same peat layer as ANTW-316, but $10 \mathrm{~m} \mathrm{NW}$. Comment: date agrees with IRPA-286 (Baeteman et al, 1979; Baeteman, 1981; Dauchot-Dehon, Van Strydonck \& Heylen, 1981a), in same strat position.

\section{ANTW-321. Booitshoeke 4}

$3130 \pm 50$

Reed rhizomes from intercalated clay layer, $10 \mathrm{~cm}$ thick, between upper and lower peat layers, 130 to $140 \mathrm{~cm}$ depth, immediately underlying ANTW-316. Comment: reed rhizomes are ca 565 yr younger than wood in overlying peat. Preliminary diatom analysis of this clay layer, which was previously observed in borings in that area (Stockmans \& Vanhoorne, 1954), indicates that it was deposited under marine tidal flat conditions (L Denys, pers commun, 1985). Strat position and sedimentary environment support opinion of C Baeteman (Baeteman et al, 1979) that this clay layer resulted from Calais IV-B transgression. 
General Comment: ages of samples containing reed rhizomes (ANTW-316 and -321 ) reveal that they did not originate from initial colonization after clay deposition, but actually belonged to plants growing several hundreds of years after initiation of upper peat layer. Explanation by deviating carbon isotope fractionation must be rejected, as Phragmites australis belongs to C-3 (Calvin cycle) group of plants, needing little or no correction (Lerman, 1973).

The same explanation, $i e$, presence of younger reed rhizomes contaminating peat sample, is proposed for unusually young date of IRPA-345 $(3200 \pm 200 \mathrm{BP})$ originating from base of upper peat layer $(\mathrm{R}, 1981, \mathrm{v} 23, \mathrm{p}$ 346).

ANTW-304. Oostkerke

$4180 \pm 60$

Clayey peat, containing many reed rhizomes, from boring 374 (Belgian Geol Survey) at 505 to $510 \mathrm{~cm}$ depth (base of peat layer) in W Belgian coastal plain $\left(51^{\circ} 20^{\prime} 54^{\prime \prime} \mathrm{N}, 2^{\circ} 44^{\prime} 54^{\prime \prime} \mathrm{E}\right)$. Coll and subm Aug 1978 by C Baeteman and A Tassanasorn. Comment: date is ca $400 \mathrm{yr}$ too young compared with other samples from same layer, $i e$, ANTW-249, -102, IRPA-282, -288, Hv-8794 (Baeteman, 1981). However, it closely resembles date of IRPA292 (R, 1981, v 23, p 33), from same layer, also containing reed rhizomes. This reveals that reed rhizomes did not originate from initial vegetation of peat $\mathrm{fm}$. This conclusion agrees with findings on Booitshoeke series.

\section{Beerse series}

Peat and extracted humic acids from Beerse $\left(51^{\circ} 20^{\prime} 22^{\prime \prime} \mathrm{N}, 4^{\circ} 48^{\prime} 31^{\prime \prime}\right.$ E). Coll and subm Nov 1978 by R Vanhoorne and A D Dubois.

ANTW-310. Beerse 1

$9460 \pm 80$

Peat from 264 to $276 \mathrm{~cm}$ depth.

ANTW-311. Beerse 2

$6080 \pm 240$

Extracted humic acids from ANTW-310. Humic acids were extracted as above (ANTW-315).

General Comment: from strat point of view, peat corresponds to Late Glacial layers described by De Ploey (1961), Vanhoorne (1963), and Riezebos, Slotboom and Vanhoorne (Lithological expression of a palynologically deduced climatic oscillation during the Alleröd, $m s$ in preparation) in same clay pit. Obtained date is $>1000 \mathrm{yr}$ BP younger than youngest date obtained by Riezebos, Slotboom and Vanhoorne ( $\mathrm{ms}$ in preparation). This can be explained by presence of younger rootlets within peat. Relatively young date for extracted humic acids reflects their good percolation through sandy soil, overlying peat layer. Salix and Juniperus wood from peat layer is currently being analyzed for its deuterium content (Dubois, The deuterium hydrogen ratio in cellulose as a climatological and a paleoclimatological indicator, $\mathrm{ms}$ in preparation). 


\section{Wuustwezel series}

Peat and extracted humic acids from Wuustwezel $\left(51^{\circ} 25^{\prime} 15^{\prime \prime} \mathrm{N}\right.$, $4^{\circ} 35^{\prime} 43^{\prime \prime}$ E). Coll and subm June 1978 by R Vanhoorne and A D Dubois.

ANTW-300. Wuustwezel 1

Amorphous peat, 104 to $106 \mathrm{~cm}$ depth. No rootlets visible.

ANTW-308. Wuustwezel 2

$9100 \pm 30$

Amorphous peat, 104 to $106 \mathrm{~cm}$ depth, adjoining ANTW-300. No rootlets visible. Comment: significantly different age from ANTW-300 reveals contamination probably caused by younger rootlets indistinguishable from rest of peat.

\section{ANTW-303. Wuustwezel 3}

$$
10,370 \pm 80
$$

Amorphous peat, 104 to $106 \mathrm{~cm}$ depth. Visible rootlets removed.

\section{ANTW-313. Wuustwezel 4}

$8690 \pm 90$

Extracted humic acids from sample ANTW-303. Humic acids were extracted as above (ANTW-315).

General Comment: pollen diagram, characterized by dominance of Pinus and Betula without any thermophilous trees and low NAP percentages reflects Late Glacial forested landscape, which should be set in Alleröd. According to generally accepted dates for Alleröd in Europe, date was expected to be $3000 \mathrm{yr}$ older. This error is probably caused by occurrence of rootlets in peat, belonging to younger vegetation.

\section{ANTW-305. Wuustwezel 5}

$7240 \pm 80$

Slightly clayey amorphous peat, 106 to $111 \mathrm{~cm}$ depth. No rootlets visible. Comment: on palynol grounds, open park landscape with a few specimens of Betula and Salix is inferred. However, Salix and Betula may represent dwarf specimens, playing no role in forestation. No thermophilous trees were observed. NAP pollen, in which Artemisia is more important than in Wuustwezel 4, attains almost $70 \%$. According to palynol results, this peat should belong to Older Dryas. Date obtained is $5000 \mathrm{yr}$ too young. There is no doubt that peat was contaminated.

\section{REFERENCES}

Baeteman, C, (ms) 1981, De Holocene ontwikkeling van de Westelijke Kustvlakte (België): PhD dissert, Univ Brussels, 297 p.

Baeteman, C, Verbruggen, C, with Dauchot-Dehon, M, Heylen, J and Van Strydonck, M, 1979 , New approach to the evolution of the so-called surface peat in the western coastal plain of Belgium: Geol Service Belgium, Prof paper, v 1 1, no. 167.

Dauchot-Dehon, M, Van Strydonck, M and Heylen, J, 1981 a, Institut Royal du Patrimoine Artistique radiocarbon dates VII: Radiocarbon, v 23, no. 1, p 33-37. 1981 b, Institut Royal du Patrimoine Artistique radiocarbon dates VIII: Radiocarbon, v 23, no. 3, p 345-351.

De Ploey, J, 1961, Morfologie en kwartair-stratigrafie van de Antwerpse Noorderkempen: Acta Geog Lovaniensia, Leuven, v 1, 130 p. 
Lerman, J C, 1973, Carbon 14 dating: Origin and correction of isotope fractionation errors in terrestrial living matter, in Rafter, T A and Grant-Taylor, T, eds, Internatl conf on radiocarbon dating, 8th, Proc: Wellington, Royal Soc New Zealand, p H16-H28.

Stockmans, F and Vanhoorne, R, 1954, Etude botanique du gisement de tourbe de la région de Pervijze (Plaine maritime Belge): Mém Inst Royal Sci Nat Belgique, v 130, 144 p.

Vanhoorne, R, 1963, Le niveau d'Alleröd de Becrse (Campine Belge): Grana Palynol, v 4, p $449-451$.

Vanhoorne, R and Van Dongen, W, 1976, Antwerp University radiocarbon dates I: Radiocarbon, v 18 , no. 2 , p 151-160.

Vanhoorne, R and Van Strydonck, M, 1977, Antwerp University radiocarbon dates II: Radiocarbon, v 19, no. 3, p 383-388.

Vanhoorne, R, Van Strydonck, M and Dubois, A D, 1978, Antwerp University radiocarbon dates III: Radiocarbon, v 20, no. 2, p 192-199. 